\title{
KOORDINASI KEPOLISIAN DAN DINAS PERHUBUNGAN DALAM PENERTIBAN BECAK MOTOR DI KOTA MAKASSAR
}

\author{
Qamal \\ Universitas Indonesia Timur
}

\begin{abstract}
Bentor is a means of transportation that has the ability to reach all areas of the city / countryside, travel time and operation, and affordable cost by the community, but the presence of bentor in Makassar, which is now starting to cause overlapping routes between different types of public transport motors. Lack of regulation in the enforcement of Law No. 22 of 2009 About Traffic and Road Transportation and the Mayor of Makassar Regulation number 22 of 2012 concerning the operational control bentor vehicles, is expected to be in control of the main road transport user motor tricycles.
\end{abstract}

Keywords: Coordination of Control Transport in Makassar

\section{PENDAHULUAN}

Bentor merupakan alat transportasi yang mempunyai kemampuan menjangkau seluruh wilayah kota/pedesaan, waktu tempuh dan operasi, serta biaya yang terjangkau oleh masyarakat namun keberadaan bentor di Kota Makassar, yang saat ini mulai menyebabkan terjadinya tumpang tindih trayek antara berbagai jenis mora angkungan umum. Di beberapa tempat, bentor sudah beroperasi pada jalan utama, dan menjadi faktor pemicu konflik sosial karena itu, tidak boleh lagi untuk membiarkan bentor seenaknya berputarputar dalam kota di Makassar.

Pemerintah daerah Kota Makassar dalam melihat hal ini ikut andil untuk pengendalian tersebut hingga mengeluarkan peraturan Walikota Makassar mengenai Zona wilayah operasional bentor yakni Peraturan Wali Kota Makassar nomor 22 tahun 2012 tentang pengendalian operasional kendaraan bentor. Dalam perwali ini kendaraan bentor hanya dibolehkan beroperasi di empat kecamatan, yakni Kecamatan Manggala, Tamalate, Biringkanaya dan Kecamatan Tamalanrea.
Peraturan yang ditetapkan oleh walikota Makassar tersebut bertujuan untuk mengatur pengguna bentor agar tetap tetib dan mengikuti jalur yang telah ditetapkan, karena keleluasaan para pemilik bentor selama ini dalam mengoperasikan kendaraannya di dalam Kota Makassar dinilai juga sebagai salah satu penyebab kemacetan. Namun dalam hal ini Pemerintah Kota (Pemkot) Makassar tak berdaya jika harus sendiri menangani aturan tersebut sehingga ditaati oleh pihak yang terkait, terlebih lagi saat ini keberadaan bentor di Makassar dianggap telah melanggar dan mesti ditertibkan langsung oleh Kepolisian dalam hal ini Polisi yang berwenang untuk menertibkan kendaraan di jalan adalah Polisi Lalu Lintas. Selain Kepolisian, Dinas Perhubungan juga ikut bertugas untuk penataan operasi Becak Motor agar tata ruang operasional memperhatikan akses kendaraan umum di wilayah Kota Makassar. Jadi dalam hal ini Kepolisian dan Dinas Perhubungan melakukan koodinasi untuk terealisassinya pengguna bentor yang tertib.

Penegakan UU Nomor 22 diharapkan mampu menjadi pengendali 
bagi pengguna angkutan jalan utamanya becak motor.Untuk itu penulis tertarik melakukan penelitian di Kota Makassar untuk melihat bagaimana koordinasi Dinas Perhubungan dan Kepolisian dalam menertibkan becak motor.

\section{KAJIAN TEORI}

\section{Pengertian Koordinasi}

Menurut Sutarto (2006:145-146)

koordinasi sebenarnya dapat dipakai satu istilah yaitu keselarasan.Baik kesatuan tindakan, kesatuan usaha, penyesuaian antar bagian, keseimbangan antar bagian maupun sinkronisasi semuanya berdasarkan keselarasan.Atas dasar itu, koordinasi dapat berasaskan bahwa di dalam organisasi harus ada keselarasan aktivitas antar satuan organisasi atau keselarasan antar pejabat.

Kondinasi dalam bukunya Syafiie (2011: 34) mengkoordinasikan berarti mengikat bersama, menyatukan dan menyelaraskan semua kegiatan dan usaha. Sedangkan menurut Goerge R. Terry dalam Syafiie (2011: 34) Maksudnya koordinasi adalah sinkronisasi yang teratur dari usaha-usaha untuk menciptakan pengaturan waktu yang terpimpin dalam hasil pelaksanaan yang harmonis dan bersatu untuk menghasilkan tujuan yang telah ditetapkan.

\section{Sifat Koordinasi}

Menurut Hasibuan (2007: 87) bahwa terdapat tiga sifat dalam koordinasi, yaitu:

a. Koordinasi adalah dinamis bukan statis.

b. Koordinasi menekankan pandangan menyeluruh oleh seorang koordinator (manager) dalam rangka mencapai sasaran.

c. Koordinasi hanya meninjau suatu pekerjaan secara keseluruhan. Asas koordinasi adalah asas skala (hierarki) artinya koordinasi itu dilakukan menurut jenjang-jenjang kekuasaan dan tanggung jawab yang disesuaikan dengan jenjang-jenjang yang berbeda- beda satu sama lain. Tegasnya, asas hierarki ini bahwa setiap atasan (koordinator) harus mengkoordinasikan bawahan langsungnya.

\section{Syarat-Syarat Koordinasi}

Menurut Hasibuan (2007: 88) mengemukakan terdapat empat syarat koordinasi, yaitu:

a. Sense of cooperation (perasaan untuk kerjasama ), ini harus dilihat dari sudut bagian perbagian bidang pekerja, bukan orang per orang.

b. Rivalry, dalam perusahaan-perusahaan besar sering diadakan persaingan antara bagian-bagian, agar bagian-bagian ini berlomba-lomba untuk mencapai kemajuan.

c. Team spirit, artinya satu sama lain pada setiap bagian harus saling menghargai.

d. Esprit de corps, artinya bagian-bagian yang diikutsertakan atau dihargai, umumnya akan menambah kegiatan yang bersamangat."

\section{Tujuan Koordinasi}

Koordinasi sangat diperlukan

dalam manajemen, terutama untuk menyatukan kesamaan pandangan antara berbagai pihak yang berkepentingan dengan kegiatan dan tujuan organisasi. Koordinasi diperlukan untuk menghubungkan bagian yang satu dengan bagian yang lain sehingga tercipta suatu kegiatan yang terpadu mengarah pada tujuan umum lembaga sebagaimana jarijari kerangka payung. Tanpa koordinasi, spesialisasi dan lembagian kerja yang dilakukan pada setiap usaha kerja sama akan sia-sia karena setiap bagian cenderung hanya memikirkan pekerjaan atau tugas masing-masing dan melupakan tujuan lembaga secara keseluruhan.

\section{Ciri-Ciri Koordinasi}

\begin{tabular}{lrr}
\multicolumn{1}{c}{ Menurut } & $\begin{array}{r}\text { Soewarno } \\
\text { bukunya }\end{array}$ \\
Administrasi & Pemerintahan & dalam \\
Pembangunan Nasional (1991), ciri-ciri
\end{tabular}


a. Tanggung jawab koordinasi terletak pada pimpinan

b. Koordinasi adalah suatu usaha kerja sama

c. Koordinasi adalah proses yang terusmenerus (continues process)

d. Adanya pengaturan usaha kelompok secara teratur

e. Konsep kesatuan tindakan

f. Tujuan koordinasi adalah tujuan bersama (common purpose)

\section{Tipe Dan Bentuk Koordinasi}

Menurut Inu Kencana Syafiie (2011: 35) bahwa terdapat tiga bentuk koordinasi, yaitu :

$\begin{array}{lcc}\text { a. Koordinasi } & \text { horizontal adalah } \\ \text { penyelarasan } & \text { kerjasama } & \text { secara }\end{array}$ harmonis dan singkron antara lembagalembaga yang sederajat misalnya antara Muspida Kecamatan (Camat, Kapolsek, Dan Danramil), Muspida Kabupaten (Bupati, Danramil Dan Kapolres), Muspida Propinsi (Gubernur, Pangdam Dan Kapolda).

b. Koordinasi vertikal adalah penyelarasan kerjasama secara harmonis dan singkron dari lembaga-lembaga yang sederajat lebih tinggi kepada lembagalembaga lain yang derajatnya lebih rendah.

c. Koordinasi fungsional adalah penyelarasan kerjasama secara harmonis dan singkron antara lembagalembaga yang memiliki kesamaan dalam fungsi pekerjaan.

Menurut Hasibuan (2007: 86-87)

bahwa terdapat dua tipe koordinasi, yaitu :

a. Koordinasi vertikal adalah kegiatankegiatan penyatuan, pengarahan yang dilakukan oleh atasan terhadap kegiatan-kegiatan unit-unit, kesatuankesatuan kerja yang ada di bawah wewenang dan tanggung jawabnya.

b. Koordinasi horisontal adalah mengkoordinasikan tindakan-tindakan atau kegiatan-kegiatan penyatuan, pengarahan yang dilakukan terhadap kegiatan-kegiatan dalam tingkat organisasi (aparat) yang setingkat.
Di dalam koordinasi terdapat Terdapat 3 (tiga) macam saling ketergantungan di antara satuan-satuan organisasi seperti diungkapkan oleh Thompson dalam (Handoko, 2003: 196), yaitu :

1. Saling ketergantungan yang menyatu (pooled interdependence), bila satuansatuan organisasi tidak saling tergantung satu dengan yang lain dalam melaksanakan kegiatan harian tetapi tergantung pada pelaksanaan kerja setiap satuan yang memuaskan untuk satuan hasil akhir.

2. Saling ketergantungan yang berurutan (sequential interdependence), dimana satuan-satuan organisasi harus melakukan pekerjaan terlebih dahulu sebelum satuan lain dapat bekerja.

3. Saling ketergantungan timbal balik (reciprocal interdependence), merupakan hubungan memberi dan menerima antar satuan organisasi.

\section{Koordinasi Kepolisian dan Dinas Perhubungan dalam Penertibaan Becak Motor di Kota Makassar}

Populasi kendaraan umum jenis becak motor atau bentor di kota Makassar ini kian tak terkendali, Jumlahnya yang semakin banyak membuat pemerintah terkait tak dapat melakukan penertiban secara sepihak. Pasalnya penertiban bentor tak hanya melibatkan satu Dinas pemerintahan, melainkan lintas sektor yang juga memiliki tanggung jawab untuk menertibkan bentor.

Pemkot Makassar memberikan kebijakan kepada Dinas Perhubungan Kota Makassar untuk melakukan pemetaan wilayah operasional bentor, dengan memperhatikan akses kendaraan umum di wilayah terkait.Pengoperasian bentor dibatasi di empat wilayah yang ditetapkan oleh Pemerintah Kota Makassar sebagai regulasi pelarangan alat transportasi becak motor.Di beberapa Jalan utama dan jalan protokol. Regulasi tersebut dijelaskan dalam Peraturan Wali Kota Makassar Nomor 22 Tahun 2012 tentang 
pengendalian operasional kendaraan bentor Dalam Perwali ini Kendaraan Bentor hanya diperbolehkan beroperasi di empat kecamatan , yakni Kecamatan Manggala, Tamalate, Biringkanaya, dan Tamalanrea.

Demikian Bentor merupakan alat transportasi dari kendaraan Motor yang diubah modifikasi dan kontruksi dengan registrasi dan identifikasi ulang maka dari itu harus dilakukan uji tipe ulang kendaraan bentor oleh Dinas Perhubungan sebagaimana dalam UU No.22 tahun 2009 tentang Lalu Lintas dan Angkutan.

Demikian halnya kewenangan masing-masing petugas baik dari Dinas Perhubungan maupun Kepolisian dalam hal ini yang bertugas di bidang penegakan aturan lalu lintas atau polisi lalu Lintas (Polantas) sudah di atur dalam beberapa bagian tugas yang berbeda namun perbedaan ini menjadi sebuah acuan untuk dilaksanakannya koordinasi agar tercapainya kesatuan tindakan antar unitunit yang terkait dan Peraturan Wali Kota Makassar nomor 22 tahun 2012 tentang Pengendalian Operasional Kendaraan Bentor dapat dipatuhi oleh pengguna becak motor di Kota Makassar.

\section{METODE PENELITIAN}

Penelitian yang di gunakan adalah.penelitian deskripsif yaitu mengungkapkan atau memotret situasi sosial yang diteliti secara menyeluruh, luas dan mendalam. Penelitian ini fokusnya adalah penggambaran peran dan koordinasi Dinas Perhubungan dan Polisi serta faktor yang mempengaruhi koordinasi.

Data yang dikumpulkan dalam penelitian ini bersumber dari para informan, hasil observasi terhadap peristiwa atau aktivitas dalam koordinasi Kepolisian dan Dinas Perhubungan, serta fakta-fakta dokumen yang berkaitan dengan fokus penelitian. Data yang di perlukan terdiri dari data primer, yaitu data yang sumbernya diperoleh dari hasil pengamatan langsung terhadap objek yang diteliti.Sumber datanya diperoleh melalui wawancara dan observasi langsung terhadap obyek penelitian.Sedangkan data sekunder, yaitu data yang sumbernya diperoleh dari perpustakaan, referensi, dokumentasi dan bahan-bahan yang berkaitan dengan variabel penelitian. Sampel ditetapkan secara purposive sampling, berdasarkan pertimbangan yaitu keterlibatan dalam kegiatan koordinasi dalam penertiban becak motor dan yang bersangkutan memahami isu yang dipersoalkan dalam penelitian ini.

Teknik analisis data yang digunakan adalah analisis deskriptif kualiatif, tehnik ini menjelaskan dan menggambarkan keadaan sesungguhnya tentang objek penelitian dan didukung dengan tabulasi sederhana dan tehnik presentase sehingga dapat dengan jelas dilihat data-data yang diperoleh adalah data yang betul-betul yang sesuai dengan keadaan yang sebenarnya dengan tingkat kesalahan yang relatif kecil.

\section{HASIL DAN PEMBAHASAN}

\section{Koordinasi Kepolisian dan Dinas Perhubungan dalam Penertiban Becak Motor di Kota Makasssar.}

Fenomena becak motor alias bentor mulai merambah kota, hal ini patut dicermati. Sebab, saat hadirnya bentor tentu membawa ironi.Sudah seringkali keluhan muncul dengan hadirnya bentor. Sebab, kendaraan yang sulit diidentifikasi sebagai becak atau sebagai motor ini sudah masuk ke jalan-jalan besar sebut misalnya, Jalan Boulevard, Jalan A. P. Pettarani, Jalan Pengayoman, termasuk Jalan Perintis Kemerdekaan, dan banyak lagi jalan lainnya. PadahalPemerintah Kota Makassar telah mengeluarkan Peraturan Walikota Makassar mengenai Zona wilayah operasional bentor yakni Peraturan Wali Kota Makassar nomor 22 tahun 2012 tentang pengendalian operasional kendaraan bentor. Dalam perwali ini kendaraan bentor hanya dibolehkan beroperasi di empat kecamatan, yakni 
Kecamatan Manggala, Tamalate, Biringkanaya dan Kecamatan Tamalanrea.

Masuknya bentor menambah kesemrawutan yang terjadi akan tetapi meski sudah banyak keluhan, sejauh ini becak motor tetap beroperasi meski melanggar peraturan yang telah ditetapkan.

Berdasarkan hasil tinjauan dokumen dan studi lapangan, untuk mengatasi becak motor di Kota Makassar ini, memang tidak bisa dilakukan oleh satu instansi saja. Butuh koordinasi antara Satuan Lalu Lintas Polrestabes Makassar dengan Dinas Perhubungan harus bersinergi secara maksimal dalam menjalankan tugasnya, sehingga permasalahan becak Motor sedikit demi sedikit bisa teratasi. Untuk melaksanakan koordinasi dalam penanggulangan kemacetan lalu lintas ada beberapa prinsip yang perlu diterapkan diantaranya :

\section{Kesepakatan}

Kesepakatan

adalah

kesepakatan kerjasama antara Instansi terkait (Satuan Lalu Lintas Polrestabes Makassar dengan Dinas Perhubungan). Kesepakatan kerja bersama memberikan keunggulan dari perundingan bersama dan kesepakatan yang dihasilkannya adalah menyediakan metode untuk pengaturan kondisi kerja oleh mereka yang terkait secara langsung. Dengan kesepakatan kerja bersama akan tercipta suatu kepastian dalam segala hal yang berhubungan dalam hal penanggulangan becak motor dikota Makassar.

Berdasarkan penuturan informan diatas penulis menyimpulkan bahwa dalam kerjasama, antar kedua bela pihak tidak harus memiliki kekuatan yang sama besar, tetapi yang lebih utama adalah kesepakatan yang jelas dari kerjasama tersebut. Dengan demikian, kesuksesan kerjasama tidak akan dicapai kalau hanya satu pihak saja yang berperan, sedangkan pihak lainnya hanya menuntut hasil. Oleh karena itu sebelum kesepakatan kerjasama disepakati, harus jelas dulu apa saja yang disepakati beserta aturan yang berlaku didalamnya jadi dalam kerjasama usaha harus dimunculkan rasa kesadaran memiliki sehingga melahirkan rasa bertanggung jawab atas apa yang telah disepakati dalam kerjasama.

2. Ketaatan dan loyalitas

Ketaatan dan loyalitas yaitu kepatuhan dan kesetiaan serta dari setiap pihak instansi terkait (Satuan Lalu Lintas Polrestabes Makassar dengan Dinas Perhubungan Kota Makassar) terhadap bagian tugas masing-masing serta jadwal yang telah ditetapkan.Ketaatan dan loyalitas meningkatkan kemauan instansi untuk bekerja sama.

3. Kerjasama

Dalam mencapai tujuan bersama, kerja sama memberikan manfaat yang besar bagi kerja suatu organisasi. Kerjasama mendorong berbagai upaya individu agar dapat bekerja lebih produktif, efektif, dan efisien.Berdasarkan hasil wawancara dengan informan AG selaku staf Urbin Lantas Polrestabes Kota Makassar :"Sejauh ini kami masih melakukan kerjasama terlebih lagi karena keberadaaan bentor yang semakin banyak jumlahnya jadi kami harus berdampingan satu sama lain untuk penertibannya.

Hasil wawancara tersebut didukung dengan jawaban informan AR selaku Staf bagian Lalu Lintas Dinas Perhubungan Kota Makassar "Wewenang kami itu sudah ditetapkan masing-masing akan tetapi dalam penertiban bentor itu kita tetap bekerjasama agar tujuan bersama juga dapat tercapai dengan cepat.

Hasil wawancara antara

Satuan Lalu Lintas Kota Makassar dengan Dinas Perhubungan Kota Makassar dapat diketahuai dalam hal pelakasanaa 
penanggulangan becak motor dikota Makassar mereka melakukan kerjasama dengan saling berdampingan agar tujuan bersama dapat tercapai.

2. Tukar informasi

Berdasarkan hasil wawancara dengan informan IL selaku staf Urbin Lantas Polrestabes Kota Makassar:“ Tentu saja dalam mejalankan tugas harus ada saling tukar informasi dan biasanya disampaikan pada forum rapat koordinasi dalam wadah forum lalu lintas dan angkutan jalan. Hasil wawancara tersebut didukung dengan jawaban informan AS selaku staf Urbin Lantas Polrestabes Kota Makassar.

3. Koordinator

Koordinator sangat penting dalam suatu usaha agar ada yang mampu memimpin dan mengatur serta mengarahkan pelaksanaan untuk menghasilkan suatu tindakan yang seragam dan harmonis pada sasaran yang telah ditentukan.

Berdasarkan hasil wawancara dengan informan IL selaku Staf Urbin Lantas Polrestabes Kota Makassar:"Sebenarnya ini sudah menjadi tanggung jawab bersama baik pada Satuan Lalu Lintas ataupun Dinas Perhubungan itu sendiri kalau masalah yang mengkoordinir disini itu pada masing-masing pimpinan untuk memberikan instruksi dan perintah kepada bawahannya."

Berdasarkan hasil wawancara antara Satuan Lalu Lintas Kota Makassar dengan Dinas perhubungan Kota Makassar dapat diketahuai untuk managgulangi becak motor dikota Makassar perlu koordinator untuk memimpin terlaksananya suatu koordinasi. Karena koordinator merupakan salah satu fungsi manajemen untuk melakukan berbagai kegiatan agar tidak terjadi kekacauan.Percekcokan,kekosongan kegiatan, dengan jalan menghubungkan, menyatukan dan menyelaraskan pekerjaan bawahan sehingga terdapat kerjasama yang terarah dalam usaha mencapai tujuan bersama.

Usaha yang dapat dilakukan untuk mencapai itu antara lain dengan memberi instruksi, perintah, mengadakan pertemuan untuk memberikan kejelasan bimbingan dan nasehat, dan bila perlu memberikan teguran.

4. Saling Menghormati

Saling menghormati dalam melakukan koordinasi adalah upaya untuk membina keserasian dan kerukunan antar organisasi agar tujuan bersama dapat terwujud.

Berdasarkan hasi pernelitian Satuan Lalu Lintas dan Dinas Perhubungan harus menanamkan sikap saling menghormati meskipun berbeda kemampuan dan wewenang.Saling menghormati juga bermaksud hubungan tersebut dapat berjalan secara harmonis, karenamasing-masing merasa hak-haknya dihormati.Sikap saling menghormati, sebagai salah satu unsur kecerdasan moral adalah elemen yang penting untuk kita tanamkan sejak dini. Dengan bisa menghormati orang lain, kita bisa menjadi insan yang lebih baik dan terpuji.

Faktor-Faktor yang Mempengaruhi Koordinasi Kepolisian dan Dinas Perhubungan dalam Penertiban Becak Motor di Kota Makassar

Dalam proses kegiatan penelitian, berdasarkan observasi dan wawancara terhadap informan maka terdapat beberapa faktor yang muncul dalam koordinasi Polrestabes Makassar dengan Dinas Perhubungan Kota Makassar dalam menertibkan becak motor di Kota Makassar sebagai berikut:

a. Kesatuan Tindakan

Pada hakekatnya koordinasi memerlukan kesadaran setiap anggota organisasi atau satuan organisasi untuk 
saling menyesuaikan diri atau tugasnya dengan anggota atau satuan organisasi lainnya agar anggota atau satuan organisasi tersebut tidak berjalan sendiri-sendiri.Oleh sebab itu konsep kesatuan tindakan merupakan inti dan dapat mempengaruhi koordinasi.

Berdasarkan hasil wawancara dengan staf Urbin Lantas Polrestabes Kota Makassardan Staf bagian Lalu Lintas Dinas Perhubungan Kota Makassardapat pernulis simpulkan bahwa :"dalam melakukan koordinasi kalau konsep kesatuan tindakan itu tidak ada sementara tugas masingmasing instansi itu berbeda jadi sudah seharusnya kita menyatukan tindakan supaya tujuan bersama itu dapat tercapai dalam melaksanakan kewajiban untuk memperoleh suatu koordinasi yang baik dengan mengatur jadwal dan waktu dimaksudkan agar kesatuan usaha itu dapat berjalan sesuai dengan waktu yang telah direncanakan.

b. Komunikasi

Berdasarkan wawancara dari informan tersebut mengatakan bahwa komunikasi tercapainya koordinasi karena komunikasi merupakan suatu proses pertukaran informasi antar kelompok satu dengan kelompok lainnya dan dengan adanya komunikasi partisipasi anggota yang melakukan kerjasama baik anatara anggota dalam satu organisasi yang sama maupun kerjasama antar organisasi yang berbeda akan semakin tinggi dan dengan komunikasi akan dapat menyampaikan tugas serta hal-hal yang penting yang berkaitan dengan pekerjaan masing-masing.

c. Pembagian Kerja

Secara teoritis tujuan dalam suatu organisasi adalah untuk mencapai tujuan bersama dimana individu tidak dapat mencapainya sendiri.Kelompok dua atau lebih orang yang berkeja bersama secara kooperatif dan dikoordinasikan dapat mencapai hasil lebih daripada dilakukan perseorangan.Dalam suatu organisasi, tiang dasarnya adalah prinsip pembagian kerja (Division of labor). Prinsip pembagian kerja ini adalah maksudnya jika suatu organisasi diharapkan untuk dapat berhasil dengan baik dalam usaha mencapai tujuanya, maka hendaknya lakukan pembagian kerja.Dengan pembagian kerja ini diharapkan dapat berfungsi dalam usaha mewujudkan tujuan suatu organisasi.

Dari hasil wawancara tersebut didukung dengan jawaban informan Staf bagian Lalu Lintas Dinas Perhubungan danDinas Kepolisian, kami membagi tugas sesuai wewenang kami kalaupun kami melakukan sendiri otomatis kami tidak bisa melakukan penilangan karena kami tidak punya wewenang jadi dengan pembagian tugas satu persatu masalah diselesaikan hingga tujuan yang kita inginkan bersama bisa dengan mudah diatasi.

d. Penguatan Melalui Hukum

Pemkot Makassar memberikan kebijakan kepada Dinas Perhubungan Kota Makassar untuk melakukan pemetaan wilayah operasional bentor, dengan memperhatikan akses kendaraan umum di wilayah terkait. Pengoperasian bentor dibatasi di empat wilayah yang ditetapkan oleh Pemerintah Kota Makassar sebagai regulasi pelarangan alat transportasi becak motor. Di beberapa Jalan utama dan jalan protokol. Regulasi tersebut dijelaskan dalam Peraturan Wali Kota Makassar Nomor 22 Tahun 2012 tentang pengendalian operasional kendaraan bentor Dalam Perwali ini Kendaraan Bentor hanya diperbolehkan beroperasi di empat kecamatan, yakni Kecamatan Manggala, Tamalate, Biringkanaya, dan Tamalanrea. 
Bentor merupakan alat transportasi dari kendaraan motor yang diubah modifikasi dan kontruksi dengan registrasi dan identifikasi ulang maka dari itu harus dilakukan uji tipe ulang kendaraan bentor oleh Dinas Perhubungan sebagaimana dalam UU No.22 tahun 2009 tentang Lalu Lintas dan Angkutan Jalan Pasal 52, ayat 3 dan 4 . Demikian juga dijelaskan dalam Undang-Undang Nomor 22 Tahun 2009 tentang Lalu Lintas dan Angkutan Jalan pasal 12 dimana dijelaskan fungsi-fungsi seperti pengaturan, penjagaan, pengawalan, dan patrol Lalu Lintas bukan menjadi kewenangan Dinas Perhubungan melainkan kewenangan petugas Kepolisian. Seperti dalam Pasal 262.Lebih jelas lagi du tegaskan dalam aturan UU No 22 Tahun 2009 itu Dinas Perhubungan tidak berwenang untuk melakukan pengawasan kecuali didampingi oleh satuan polisi jadi dengan adanya aturan ini sangat mendukung berjalannya koordinasi untuk mewujudkan tertibnya bentor.

Hukum memainkan peranan yang sangat penting untuk mengatur agar kepentingan untuk meweujudkan tujuan bersama yakni menertibkan becak motor di Kota Makassar tidak bersinggungan dengan kepentingan masing-masing instansi. Dengan adanya penguatan hukum mengantar tugas masing-masing instansi diharapkan fungsi hukum tersebut dapat berjalan jika fungsi hukum tidak berjalan maka tugas yang telah menjadi ketetapan akan terabaikan.

\section{KESIMPULAN}

Koordinasi Kepolisian dan Dinas Perhubungan Kota Makassar dalam penertiban becak motor di Kota Makassar,sudah menunjukkan efektifitas dalam menjalankan tugas masing-masing, Hal yang menjadi patokan/ standar dalam penilaian yaitu:Hubungan koordinasi Kepolisian dan Dinas Perhubungan Kota
Makassar telah berjalan dengan baik dengan menempatkan satuan Polisi sebagai yang berwenang untuk menegakkan hukum berupa teguran lisan, teguran tertulis atau tilang dan penyitaan bentor sementara itu Dinas Perhubungan berwenang melaksanakan pengawasan terhadap peraturan yang telah ditetapkan dengan tetap berkoordinasi dengan unsur Kepolisian dengan berdasarkan kesepakatan yang telah dibuat antara Kepolisian dan Dinas Perhubungan dan, tujuan bersama yang merupakan standar yang ingin dicapai menjadi suatu motivasi untuk kedua belah pihak yang berkoordinasi, serta komitmen, yang merupakan tingginya partisipasi dan loyalitas kedua belah pihak dalam kegiatan koordinasi.

Faktor determinan yang mempengaruhi proses koordinasi Kepolisian dan Dinas Perhubungan dalam menertibkan becak motor di Kota Makassar, baik yang berasal dari dalam maupun yang berasal dari luar meliputi kesatuan tindakan, komunikasi, pembagian kerja dan penguatan melalui hukum.

\section{DAFTAR PUSTAKA}

Handoko, T .Hani,. 2003, Manajemen, Edisi Ke II, Yogyakarta : BPFE.

Hasibuan, Malayu S P. 2007. Manajemen sumber daya manusia, Jakarta : Haji Masagung.

Peraturan Wali Kota Makassar Nomor 22 Tahun 2012 Tentang Pengendalian Operasional Kendaraan Bentor

Peraturan Pemerintah Kota Makassar Tahun 2009 Tentang Uraian Tugas Jabatan Struktural pada Dinas Perhubungan Kota Makassar

Sutarto. 2006. Dasar-Dasar Organisasi.

Yogyakarta: Gajah Mada University Press.

Syafiie, Inu Kencana. 2011, Manaejemen Pemerintahan, Cetakan Pertama.Bandung : Pustaka Reka Cipta. 